\title{
PENGARUH E-LEARNING SEBAGAI MEDIA KOMUNIKASI PEMBELAJARAN TERHADAP EFIKASI DIRI MAHASISWA UPNVJ
}

\author{
Lusia Handayani ${ }^{1}$, Vina Mahdalena ${ }^{2}$ \\ 1,2Prodi IImu Komunikasi FISIP UPN Veteran Jakarta
}

Naskah diterima tanggal 14-11-2020, direvisi tanggal 23-02-2021 disetujui tanggal 26-02-2021

\begin{abstract}
Abstrak. Self Efficay atau Efikasi diri adalah penilaian pribadi atau keyakinan seseorang akan kemampuannya dalam melakukan serangkaian tindakan yang diperlukan untuk menghadapi situasi mendatang. Self Efficacy pertama kali diperkenalkan oleh Albert Bandura. Penelitian ini bertujuan untuk mengukur seberapa besar keyakinan keberhasilan seorang mahasiswa (self efficacy) dalam menyelesaikan tugas yang dilakukan setelah mengikuti pembelajaran dengan media e-learning 4.0. Teori pada penelitian ini adalah New Media yang bisa menggambarkan konsep elearning sebagai bentuk media baru dan efikasi diri sebagai efek dari new media. Metode yang digunakan dalam penelitian ini adalah metode kuantitatif dengan pendekatan survey sebanyak 96 mahasiswa UPN. Hasil penelitian menunjukkan bahwa terdapat pengaruh antara elearning 4.0 sebagai media komunikasi pembelajaran terhadap efikasi diri mahasiswa UPNVJ Angkatan 2019/2020. Berdasarkan hasil perhitungan uji hipotesis yang diperoleh melalui uji t yaitu sebesar 4.9538 sedangkan $t$ tabel 1.66123, maka dapat ditarik kesimpulan bahwa HO ditolak dan Ha diterima yang berarti media komunikasi pembelajaran e4.0 berpengaruh terhadap efikasi diri mahasiswa UPNVJ. Tidak semua mahasiswa mampu menggunakan elearning 4.0 sebagai media komunikasi pembelajaran dikarenakan kurangnya efikasi diri dalam dirinya saat menggunakan media teknologi, ini dibuktikan dengan hasil jawaban kuesioner bahwa mereka merasa tidak mampu untuk menangani kendala teknis atau kesulitan yang dihadapinya pada saat menggunakan elearning 4.0 sebagai media komunikasi pembelajaran. Sehingga ketika mereka menemukan kesulitan dalam menggunakan elearning 4.0 ataupun mendengar hal negatif dari penggunaan elearning 4.0 efikasi atau keyakinan diri mereka menurun. Selain itu mereka merasa elearning 4.0 belum bisa menggantikan komunikasi dua arah dan komunikasi tatap muka seperti aktivitas mereka di kelas.
\end{abstract}

Kata kunci: efikasi diri, e-learning 4.0, media komunikasi, pembelajaran

Abstract. Self Efficay or self-efficacy is a person's personal judgment or belief in his ability to take a series of actions needed to face future situations. Self Efficacy was first introduced by Albert Bandura. This study aims to measure how much confidence in the success of a student (selfefficacy) in completing tasks that are carried out after participating in learning with e-learning media 4.0. The theory in this research is New Media which can describe the concept of elearning as a form of new media and self-efficacy as the effect of new media. The method used in this research is a quantitative method with a survey approach of 96 UPN students. The results showed that there was an influence between e-learning 4.0 as a learning communication medium on the self-efficacy of UPNVJ Class 2019/2020 students. Based on the results of the calculation of the hypothesis test obtained through the $t$ test, which is 4.9538 while the $t$ table is 1.66123 , it can be concluded that HO is rejected and $\mathrm{Ha}$ is accepted, which means that learning communication media e4.0 has an effect on the self-efficacy of UPNVJ students. Not all students are able to use elearning 4.0 as a learning communication medium due to a lack of self-efficacy when using technology media, this is evidenced by the results of the questionnaire answers that they feel unable to handle technical constraints or difficulties they face when using elearning 4.0 as a learning communication medium. So that when they find difficulties in using e-learning 4.0 or hearing negative things from using elearning 4.0, their efficacy or self-confidence decreases. In addition, they feel that e-learning 4.0 cannot replace two-way communication and face-to-face communication like their activities in class.

Keywords: e-learning 4.0, communication of media, learning, self eficacy 


\section{PENDAHULUAN}

Saat ini Corona menjadi pembicaraan yang hangat. Di belahan bumi manapun corona masih mendominasi ruang publik. Dalam waktu singkat saja, namanya menjadi trending topik, dibicarakan di sana-sini, dan diberitakan secara masif di media cetak maupun elektronik. Adanya wabah corona membuat beberapa negara menetapkan kebijakan untuk memberlakukan lockdown dalam rangka mencegah penyebaran virus corona. Di Indonesia sendiri, diberlakukan kebijakan Pembatasan Sosial Berskala Besar (PSBB) untuk menekan penyebaran virus ini. Karena hal itu, maka semua kegiatan yang dilakukan di luar rumah harus dihentikan sampai pandemi ini mereda. Salah satu bentuk kegiatan yang dihentikan oleh pemerintah adalah kegiatan belajar mengajar di kampus atau di sekolah. Metode pembelajaran yang awalnya dilakukan secara tatap muka, kini menjadi bermedia. Berbagai cara dilakukan agar aktivitas belajar mengajar tidak terhenti karena wabah ini, alternatif yang digunakan saat ini adalah metode pemebelajaran daring (dalam jaringan).

Sistem pembelajaran daring (dalam jaringan) merupakan sistem pembelajaran tanpa tatap muka secara langsung antara pendidik dan peserta didik tetapi dilakukan melalui online yang menggunakan jaringan internet. Pendidik harus memastikan kegiatan belajar mengajar tetap berjalan, meskipun peserta didik berada di rumah. Solusinya, pendidik dituntut dapat mendesain media pembelajaran sebagai inovasi dengan memanfaatkan media daring (online).

Aturan pembelajaran daring diatur dalam Surat Edaran Nomor 4 Tahun 2020 tentang Pelaksanaan Kebijakan Pendidikan dalam Masa Darurat Penyebaran Corona Virus Disease (COVID-19), yang dikeluarkan oleh Kementerian Pendidikan dan kebudayaan Republik Indonesia. Walaupun COVID-19 memberikan dampak terhambatnya seluruh bentuk kegiatan manusia, namun pandemi ini mampu mengakselerasi pendidikan 4.0. Sistem pembelajaran dilakukan jarak jauh dengan memanfaatkan teknologi informasi. Berdasarkan kutipan langsung dari portal berita UGM tahun 2020, Guru besar University of Applied Science and Arts, Hannover, Germany and Senior Experten Services (SES) Germany, Prof. Dr. Gerhad Fortwengel, menyebutkan wabah corona ini justru menjadi katalis hebat yang memacu dunia pendidikan. Seperti mendorong lebih banyak pemanfaatan teknologi informasi dalam aktivitas pembelajaran jarak jauh., namun begitu, ada tantangan besar dalam pelaksanaan model pembelajaran jarak jauh. Salah satunya, sivitas akademika belum terbiasa menggunakan sistem pembelajaran yang bersifat blended dan sepenuhnya online.

Perubahan pada seluruh aspek kehidupan manusia tidak semata-mata diakarenakan dan diawali oleh hadirnya virus corona seperti saat ini, pada kenyataannya era digitalisasi turut mendorong pada perubahan tersebut. Metode pembelajaran kini mulai beralih secara perlahan menggunakan Learning Management System (LMS) yaitu system perangkat lunak untuk kegiatan pembelajaran daring atau e-learning, model pembelajaran LMS tidak mengharuskan setiap pengajar atau pembelajar hadir di kelas, dan dapat diakses dimana saja selama masih terkoneksi dengan jaringan internet.

Salah satu institusi Pendidikan yang merapkan pembelajaran jarak jauh (PJJ) akibat COVID-19 adalah UPN Veteran Jakarta (UPNVJ), saat ini seluruh aktivitas pembelajaran menggunakan metode daring, hal tersebut sesuai dengan Surat Edaran No.23 Tahun 2020 tentang pencegahan penyebaran COVID -19 di Lingkungan UPN Veteran Jakarta dan surat edaran No. 29 Tahun 2020 tentang pentapan masa perkuliahan jarak jauh, bahwa perkuliahan tatap muka digantikan perkuliahan jarak jauh sampai batas waktu yang ditetapkan, yaitu mulai tanggal 16 Maret sampai dengan 15 Juli 2020. Selama proses PJJ berlangsung mahasiswa belajar, diskusi dan mengerjakan tugas secara online dengan memanfaatkan system e-learning yang telah disepakati, yaitu model LMS e-learning 4.0 (selanjutnya disebut E4.0). E4.0 merupakan media pembelajaran yang dimiliki dan dikembangkan oleh UPNVJ untuk proses PJJ.

Untuk UPNVJ sendiri bukan hal yang baru menggunakan E4.0 dan tidak hanya didasari oleh adanya COVID-19 sehingga memberlakukan PJJ, namun kebiasaan menggunakan E4.0 sebagai salah satu pilihan metode pembelajaran masih sangat kurang, data yang didapat peneliti berkaitan dengan pemanfaatan e-learning 4.0 dosen tetap pengampu mata kuliah di Fakultas Fisip semester genap TA 2019/2020 pada prodi IImu Komunikasi mayoritas memanfaatkan google classroom hanya beberapa dosen yang menggunakan E4.0. Selain hal 
tersebut berdasarkan observasi peneliti sendiri beberapa alasan tidak mengharuskan mahasiswa menggunakan E4.0, salah satunya kemudahan mengakses dan penggunaan yang tidak user friendly, sehingga dipertanyakan keefektifan E4.0 sebagai media pembelajaran, yang termasuk di dalamnya merupakan bentuk aktivitas belajar mengajar, informasi dan komunikasi dosen dengan mahasiswa serta penugasan akhir sebagai evaluasi hasil pembelajaran mahasiswa. Serta memastikan mahasiswa dapat yakin bahwa metode pembelajaran E4.0 merupakan media dan sarana belajar yang tepat bagi mereka dan mengerti saat mengerjakan tugas-tugas yang diberikan. Media pembelajaran yang digunakan haruslah tepat agar efektifitas belajar mahasiswa dan tujuan dari kegiatan pembelajaran dapatlah tercapai, namun kadangkala tujuan tersebut dapat tidak tercapai dikarenakan masalah dari diri pembelajar sendiri, keyakinan diri atau efikasi bisa saja mempengaruhi efektivitas belajar, sebagaimana disebutkan Sihaloho, 2018 (Sihaloho, 2018). Efikasi diri pembelajar berpengaruh tergadap pemilihan fasilitasn ataupun media komunikasi pembelajaran yang digunakan. Pemanfaatan media teknologi informasi dan komunikasi sebagai media pembelajaran seperti computer menjadi sarana yang efektif dan efisien untuk digunakan sebagai modalitas dalam pembelajaran khususnya Ketika media komunikasi tesebut terhbung oleh jaringan internet (Anshori, 2018). Seperti yang media komunikasi pembejaran yang digunakan oleh UPNVJ dan gambaran kondisi yang telah dijelaskan sebelumnya, peneliti bermaksud melakukan penelitian dengan menggunakan dua konsep penelitian yaitu E4.0 sebagai media komunikasi pembelajaran dan efikasi diri yang terdapat dalam diri mahasiswa. Berdasarkan urgensi permasalahan yang dijabarkan di atas maka peneliti, mengkerucut pada suatu rumusan masalah sebagai yaitu Apakah terdapat pengaruh e-learning 4.0 sebagai media komunikasi pembelajaran terhadap efikasi diri mahasiswa UPNVJ dan seberapa besar pengaruh e-learning 4.0 sebagai media komunikasi pembelajaran terhadap efikasi diri mahasiswa UPNVJ ?

\section{METODE PENELITIAN}

Penelitian ini menggunakan jenis pendekatan kuantitatif. Pendekatan kuantititaif ialah pendekatan yang menggunakan angka-angka disertai ilmu statistik. Selain itu, pendekatan kuantitatif digunakan karena peneliti ingin mengukur besar tidaknya pengaruh antar variabelnya yaitu e-learning 4.0 sebagai media komunikasi pembelajran dan efikasi diri pendekatan penelitian ini sependapat dengan Kriyantono, (2012) yang menjelaskan bahwa pendekatan kuantitatif dapat menggambarkan permasalahan yang hasilnya mampu digeneralisasikan, sehingga tidak perlu lagi mementingkan keluasan data, dan diakhiri dengan hasil penelitian yang dianggap sebagai jawaban atas seluruh populasi.

Jenis penelitian yang terdapat dalam penelitian ini adalah jenis peneltiaan eksplanatif. Jenis penelitian eskplanatif merupakan jenis penelitian yang mengukur hubungan antara 2 variabel atau lebih. Jenis penelitian eksplanatif menjelaskan sebuah sebab dari suatu kejadian yang menghasilkan suatu akibat dari kejadian itu. Tujuan dari menggunakan jenis penelitian eksplanatif diantaranya menurut Prasetyo (2005): (1) Membantu dalam menghubungkan polapola yang memiliki keterkaitan yang sama dan (2) Menghasilkan hubungan sebab akibat.

Seperti penelitian ini yang mempunyai variabel $X$ e-learning sebagai media komunikasi pembelajaran yang mempengaruhi variabel $Y$ yaitu efikasi diri mahasiswa. Demi menjawab hasil ukur hubungan antara 2 variabel sebelumnya, peneliti memilih jenis penarikan data berupa teknik survei. Penarikan data survei ialah suatu cara mencari data dengan menyebarkan sebuah kuesioner. Kuesioner biasanya berisi sebuah kumpulan pertanyaan untuk mengukur variabelvariabel, hubungan dalam variabel-variabel atau pegalaman serta opini dari responden.

Populasi Populasi adalah wilayah menyeluruh dari suatu obyek yang merupakan perhatian peneliti untuk kemudian ditarik dan dicari kesimpulannya (Sugiyono, 2015). Pada penelitian ini, peneliti mengambil populasi yang berasal dari mahasiswa aktif UPN Veteran Jakarta angkatan 2019 sejumlah 2.914 mahasiswa. Alasan pengambilan populasi ini karena menurut data yang peneliti dapatkan mahasiswa 2019 lebih baru dalam mengunakan media PJJ E4.0 dibandingkan dengan angkatan 23 2016, 2017, dan 2018, sehingga peneliti ingin mengetahui kesan pertama angkatan 2019 dalam menggunakan media PJJ ini. Adapun media lain yang digunakan sebagai media PJJ di UPN Veteran Jakarta adalah Google Classroom. Maka dari itu, peneliti ingin 
mencoba untuk melihat perbandingan efektivita komunikasi dengan kedua media PJJ tersebut berdasarkan survey yang nantinya dilakukan kepada mahasiswa. Berikut merupakan data populasi mahasiswa aktif UPN Veteran Jakarta tahun ajaran 2019/2020:

Tabel 1.

Populasi Mahasiswa UPNVJ Angkatan 2019/2020

\begin{tabular}{|c|l|c|}
\hline No & \multicolumn{1}{|c|}{ Fakultas } & Jumlah Mahasiswa \\
\hline 1 & Fakultas Ekonomi dan Bisnis (FEB) & 784 \\
\hline 2 & Fakultas Kedokteran (FK) & 175 \\
\hline 3 & Fakultas Teknik (FT) & 282 \\
\hline 4 & Fakultas Imu Sosial dan Politik (FISIP) & 570 \\
\hline 5 & Fakultas Hukum (FH)) & 309 \\
\hline 6 & Fakultas IImu Komputer (FIK) & 374 \\
\hline 7 & Fakultas IImu Kesehatan (FIKES) & 420 \\
\hline \multicolumn{2}{|c|}{ Total } & $\mathbf{2 9 1 4}$ \\
\hline
\end{tabular}

Sumber Data: Biro AKPK UPNVJ

Sampel adalah sebagian dari populasi yang terpilih dan mewakili populasi tersebut. Peneliti ingin mengambil sampel dengan Teknik proportionate random sampling, yaitu pengambilan sampel dari tiap sub populasi yang jumlahnya disesuaikan dengan jumlah anggota yang ada pada sub populasi tersebut sehingga jawaban dari tiap populasi dapat terwakilkan. Berdasarkan populasi yang diketahui maka peneliti akan menggunakan rumus Yamane untuk menentukan banyaknya mahasiswa yang menjadi sampel penelitian. Setelah dihitung dan dibulatkan hasilnya adalah 96 sampel. Kemudian peneliti menghitung sampel secara berkelompok. Adapun cara penarikan sampel dari setiap kelompok yaitu:

$$
\mathrm{n} 1 \frac{N 1}{N} \mathrm{n}
$$

Tabel 2.

\begin{tabular}{|c|c|c|c|}
\hline Populasi & Jumlah & Penarikan Sampel & Sampel \\
\hline $\begin{array}{l}\text { Fakultas Ekonomi dan } \\
\text { Bisnis (FEB) }\end{array}$ & 784 & $\begin{array}{l}784 \times 90 \\
2.194\end{array}$ & 26 \\
\hline $\begin{array}{l}\text { Fakultas Kedokteran } \\
\text { (FK) }\end{array}$ & 175 & $\frac{175 \times 90}{2.194}$ & 6 \\
\hline Fakultas Teknik (FT) & 282 & $\frac{282 \times 90}{2.194}$ & 9 \\
\hline $\begin{array}{l}\text { Fakultas IImu Sosial dan } \\
\text { IImu Politik (FISIP) }\end{array}$ & 570 & $\frac{570 \times 90}{2.194}$ & 19 \\
\hline Fakultas Hukum (FH) & 309 & $\frac{309 \times 90}{2.194}$ & 10 \\
\hline $\begin{array}{l}\text { Fakultas Ilmu Komputer } \\
\text { (FIK) }\end{array}$ & 374 & \begin{tabular}{|l|}
$374 \times 90$ \\
2.194 \\
\end{tabular} & 12 \\
\hline $\begin{array}{l}\text { Fakultas IImu } \\
\text { Kesehatan (FIKES) }\end{array}$ & 420 & $\begin{array}{l}420 \times 90 \\
2.194\end{array}$ & 14 \\
\hline \multicolumn{3}{|c|}{ Total } & 96 \\
\hline
\end{tabular}

Sampel Mahasiswa UPNVJ Angkatan 2019/2020

Pada penelitian ini, untuk mendapatkan data primer dan data sekunder. Untuk data primer peneliti menggunakan kuesioner yang akan disebar melalui Google Form untuk memudahkan sampel penelitian untuk mengisinya. Peneliti akan menghubungi perwakilan dari tiap jurusan untuk membantu peneliti dalam menyebar kuesioner. Adapun skala pengukuran yang digunakan adalah skala rating yang mengukur hasil capaian sesorang atau suatu produk berdasarkan pengamatan. Pengukuran dilakukan dengan angka dimana setiap angka tersebut memiliki nilai capaian, seperti 5 = sangat setuju; 4 = setuju; 3 = cukup setuju 2 = kurang setuju; 
1 = tidak setuju. Namun pada penelitian ini peneliti hanya menggunakan 4 skala, yaitu $4=$ sangat setuju, 3 =setuju, $2=$ tidak setuju, 1 = sangat tidak setuju.

Data sekunder merupakan data yang di dapatkan oleh penulis diluar data penelitian seperti pada data primer. Guna dari data sekunder ini ialah untuk mendukung data primer yang telah didapatkan. Peneliti bisa mendapatkan data dengan cara membaca literatur berupa artikel, buku, dan jurnal. Pada saat penelitian ini dilakukan, peneliti lebih banyak mencari literatur tersebut di internet karena kondisi Pembatasan Sosial Skala Besar (PSBB) yang sedang diterapkan selama masa pandemi COVID-19.

\section{HASIL PENELITIAN DAN PEMBAHASAN}

Peneliti melakukan analisis uji korelasi untuk mengetahui pengaruh antara variabel $X$ (Media komunikasi pembalajaran E4.0) terhadap variabel $Y$ (Efikasi diri mahasiswa UPNVJ). Koefisien korelasi antara variabel $X$ dan $Y$ dilakukan dengan menggunakan SPSS versi 26. Berikut adalah hasil analisis uji korelasi:

\begin{tabular}{|c|c|c|c|}
\hline \multicolumn{4}{|c|}{ Correlations } \\
\hline & & Efikasi Diri & $\begin{array}{c}\text { E4.0 sebagai } \\
\text { Media } \\
\text { Komunikasi }\end{array}$ \\
\hline \multirow[t]{3}{*}{ Efikasi Diri } & Pearson Correlation & 1 & $.455^{\star \star}$ \\
\hline & Sig. (2-tailed) & & .000 \\
\hline & $\mathrm{N}$ & 96 & 96 \\
\hline \multirow{3}{*}{$\begin{array}{l}\text { E4.0 sebagai Media } \\
\text { Komunikasi }\end{array}$} & Pearson Correlation & $.455^{\star x}$ & 1 \\
\hline & Sig. (2-tailed) & .000 & \\
\hline & $\mathrm{N}$ & 96 & 96 \\
\hline
\end{tabular}

\section{Gambar 1. Hasil Uji Korelasi SPSS Versi 26}

Berdasarkan tabel di atas, data tersebut telah diolah di SPSS versi 26 yang dapat disimpulkan bahwa adanya korelasi antara kedua variabel tersebut. Nilai signifikansi sebesar 0.000 yang menunjukkan adanya korelasi karena terletak pada angka $<0.05$. Nilai pearson correlation sebesar 0.455 , maka menunjukkan bahwa adanya korelasi sedang karena terletak diantara $0.41 \mathrm{~s} / \mathrm{d}$ 0.60. Dari hasil data tersebut dapat disimpulkan bahwa antara variabel $X$ terhadap variabel $Y$ memiliki hubungan yang sedang, serta bentuk hubungan antara variabel $X$ dan variabel $\mathrm{Y}$ adalah positif. Dari tabel di atas dapat diketahui bahwa nilai Constant (a) sebesar 14.623, sedangkan nilai Trust (b / koefisien regresi) sebesar 0.199 , sehingga persamaan regresinya dapat ditulis sebagai berikut:

$$
\begin{aligned}
& Y=a+b X \\
& Y=14.623+0.199 X
\end{aligned}
$$

Constant sebesar 14.623 mengandung arti bahwa nilai konsisten variabel $Y$ atau efikasi diri mahasiswa UPNVJ adalah sebesar 14.623. Koefisien regresi $X$ sebesar 0.199 menyatakan bahwa jika media komunikasi pembalajaran E4.0 mengalami kenaikan sebanyak 1 poin, maka efikasi diri mahasiswa UPNVJ mengalami kenaikan sebanyak 0.199 . Koefisien regresi tersebut bernilai positif, sehingga dapat dikatakan bahwa semakin naik nilai yang didapat dari media komunikasi pembalajaran E4.0, maka semakin meningkat juga efikasi diri mahasiswa UPNVJ. Koefisien determinasi dilakukan untuk melihat seberapa besar pengaruh variabel $X$ (Media Komunikasi Pembalajaran E4.0) terhadap variabel Y (Efikasi Diri Mahasiswa UPNVJ). 


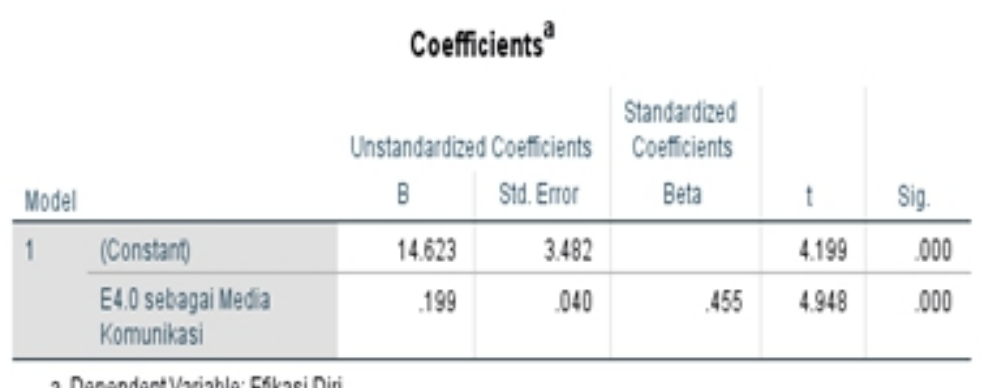

a. Dependent Variable: Efikasi Diri

\begin{tabular}{|c|c|c|c|c|c|}
\hline \multicolumn{6}{|c|}{ Model Summary } \\
\hline Model & $\mathrm{R}$ & R Square & $\begin{array}{l}\text { Adjusted R } \\
\text { Square }\end{array}$ & $\begin{array}{l}\text { Std. Error of } \\
\text { the Estimate }\end{array}$ & $\begin{array}{l}\text { Durbin- } \\
\text { Watson }\end{array}$ \\
\hline 1 & $.455^{\mathrm{a}}$ & .207 & .198 & 4.066 & 1.710 \\
\hline
\end{tabular}

Gambar 2. Koefisien Determinasi Hasil Olah SPSS Versi 26

Berdasarkan tabel di atas, dapat dirumuskan sebagai berikut:

$$
\begin{aligned}
\mathrm{Kd} & =r^{2} \times 100 \% \\
& =0.207 \times 100 \% \\
& =20.7 \%
\end{aligned}
$$

Dari hasil tabel di atas, diketahui nilai korelasi $(r)$ adalah $0.455^{2}$ dan penguatan nilai korelasi ( $r$ square) adalah $20,7 \%$. Oleh karena itu, dapat disimpulkan bahwa munculnya efikasi diri mahasiswa UPNVJ (variabel Y) terhadap media komunikasi pembalajaran E4.0 (variabel X) adalah sebesar $20,7 \% \quad r \sqrt{n-2}$ dan sisanya sejumlah $79,3 \%$ (pengurangan $100 \%$ dengan $20,7 \%) t=\frac{r \sqrt{n-2}}{\sqrt{1-r^{2}}}$ dipengaruhi oleh faktor lain yang tidak diteliti di dalam
penelitian ini.

Uji hipotesis dilakukan untuk mengetahui signifikansi koefisien antara variabel $X$ dan variabel $\mathrm{Y}$. Adapun dasar pengambilan keputusan yaitu membandingkan $t_{\text {hitung }}$ dengan $t_{\text {tabel }}$ sebagai berikut: Jika $t_{\text {hitung }}<t_{\text {tabel }}$ maka $\mathrm{H}_{0}$ diterima dan $\mathrm{H}_{\mathrm{a}}$ ditolak sedangkan Jika $t_{\text {hitung }}>\mathrm{t}_{\text {tabel }}$ maka $\mathrm{H}_{0}$ ditolak dan $\mathrm{H}_{\mathrm{a}}$ diterima.

Rumus Uji Hipotesis :

$$
\begin{aligned}
& t=\frac{0.455 \sqrt{96-2}}{\sqrt{1-0.455^{2}}} \\
& t=\frac{0.455 \sqrt{94}}{\sqrt{1-0.207}} \\
& t=\frac{4.41138867}{0.890505474} \\
& t=4.9538
\end{aligned}
$$

Berdasarkan hasil dari perhitungan dengan menggunakan uji t, maka $t$ hitung diperoleh sebesar 4.9538. Penentuan kesimpulan signifikansi dengan membandingkan $t_{\text {hitung }}$ dengan $t_{\text {tabel }}$ yaitu: penentuan dari level of significantion, dari $t_{\text {tabel }}$ nilainya ditentukan pada tingkat signifikansi 
$10 \%$ dan df $=\mathrm{n}-2$ yaitu 96-2 $=94$. Maka, $\mathrm{t}_{\text {tabel }}$ adalah 1.66123. Berdasarkan perhitungan tersebut, hasil perhitungan $t_{\text {hitung }} 4.9538>\mathrm{t}_{\text {tabel }}$ 1.66123. Maka, dapat ditarik kesimpulan bahwa $\mathrm{HO}$ ditolak dan $\mathrm{Ha}$ diterima yang berarti media komunikasi pembalajaran E4.0 berpengaruh terhadap efikasi diri mahasiswa UPNVJ.

Penelitian ini membahas tentang pengaruh media komunikasi Pembelajaran dalam bentuk e-learning dapat mempengaruhi efikasi diri seorang mahasiswa. Perkembangan teknologi informasi dan komunikasi di era Industri 4.0 telah memiliki pengaruh yang besar terhadap proses pengajaran dan pembelajaran. Kemudahan akses teknologi telah digunakan oleh para pengajar untuk memudahkan proses pembelajaran. Salah satunya adalah melalui metode pembelajaran daring, melalui jaringan internet pendidik dan peserta didik dapat berkomunikasi dalam proses belajar mengajar tanpa dibatasi dengan ruang dan waktu.

Saat ini e-learning semakin dikenal sebagai salah satu cara untuk mengatasi masalah pendidikan dan pelatihan, baik di negara-negara maju maupun di negara - negara yang sedang berkembang, khususnya Indonesia. Banyak orang menggunakan istilah yang berbeda - beda untuk e-learning. Pada prin sipnya e-learning adalah pembelajaran yang menggunakan jasa elektronik sebagai alat bantunya. Seperti yang telah diterapkan oleh UPN Veteran Jakarta yang menggunakan elaernig 4.0 sebagai media alternatif komunikasi pembelajaran. Diharapkan elearning 4.0 (e4.0) dapat memberikan kemudahan bagi dosen dan mahasiswa khususnya, guna menunjang prestasi belajar mahasiswa dalam kegiatan perkuliahan.

Salah satu faktor yang dapat menunjang keberhasilan studi mahasiswa adalah Efikasi diri, efikasi diri memiliki peran yang sangat penting atas keberhasilan seseorang. Seseorang akan mampu menggunakan potensi dirinya secara optimal apabila efikasi diri mendukungnya. Sehingga bagi seorang mahasiswa sangat perlu memiliki efikasi yang tinggi guna menunjang prestasi belajarnya, hal tersebut sesuai dengan penelitian Chemers et al. (2001) dalam Rustika, 2012 yang menyebutkan bahwa efikasi diri akademik berhubungan dengan prestasi dan penyesuaian diri, (secara langsung memengaruhi prestasi akademis, sedangkan secara tidak langsung memengaruhinya melalui harapan dan persepsi terhadap koping). Penyesuaian diri saat ini secara tergambar Ketika mahasiswa UPN Veteran Jakarta menggunakan media komunikasi baru seperti website e-learning 4.0.

Berdasarkan hasil penelitian yang telah dilakukan, diketahui bahwa terdapat hasil korelasi dan pengaruh antara media komunikasi pembelajaran elearning 4.0 terhadap efikasi diri mahasiswa UPN Veteran Jakarta angakatan 2019/2020. Hasil data tersebut didapat dari perhitungan rumus Rank Spearman yaitu, maka menunjukkan bahwa adanya korelasi sedang karena terletak diantara $0.41 \mathrm{~s} / \mathrm{d}$ 0.60. Dari hasil data tersebut dapat disimpulkan bahwa antara variabel $X$ terhadap variabel $Y$ memiliki hubungan yang sedang, serta bentuk hubungan antara variabel $X$ dan variabel $Y$ adalah positif.

Berdasarkan hasil perhitungan analisis uji regresi, diketahui constant sebesar 14.623 mengandung arti bahwa nilai konsisten variabel $Y$ atau efikasi diri mahasiswa UPNVJ angkatan 2019/2020 adalah sebesar 14.623. Koefisien regresi X sebesar 0.199 menyatakan bahwa jika media komunikasi pembalajaran E4.0 mengalami kenaikan sebanyak 1 poin, maka efikasi diri mahasiswa UPNVJ mengalami kenaikan sebanyak 0.199. Koefisien regresi tersebut bernilai positif, sehingga dapat dikatakan bahwa semakin naik nilai yang didapat dari media komunikasi pembalajaran E4.0, maka semakin meningkat juga efikasi diri mahasiswa UPNVJ.

Besar pengaruh variabel dalam penelitian ini dapat diketahui dengan perhitungan koefisien determinasi yaitu sebesar $20,7 \%$. Maka, dapat ditarik kesimpulan bahwa munculnya efikasi diri mahasiswa UPNVJ (variabel Y) terhadap media komunikasi pembalajaran E4.0 (variabel X) adalah sebesar $20,7 \%$ dan sisanya sejumlah $79,3 \%$ (pengurangan $100 \%$ dengan $20,7 \%$ ) dipengaruhi oleh faktor lain yang tidak diteliti di dalam penelitian ini.

Dari hasil kuesioner variable $X$ pada dimensi digital rata-rata responden memilih jawaban setuju yaitu pada pernyataan 6 , dengan persentase $66,7 \%$ atau sebanyak 64 responden menyatakan bahwa media komunikasi pembelajaran e4.0 dapat mengedit data tugas seperti merubah, mengirim kembali serta menghapus, selama mereka menggunakannya sebagai media komunikasi pembelajaran, dan terhubung jaringan internet.

Pada dimensi interaktif didominasi dengan jawaban tidak setuju, dengan jumlah persentase terbanyak 47,9 dan 46 responden yang menjawab tidak setuju. Angka tersebut mengartikan bahwa responden yang menjawab tidak setuju merasa chatroom yang tersedia di 
dalam e4.0 tidak berfungsi sebagai tempat bertanya mengenai tugas yang diberikan. Selain itu jumlah yang hampir sama pada dimensi ini juga menjawab tidak setuju pada pernyataan 12 yaitu dengan jumlah persentase $47 \%$ dan jumlah responden 46 menyatakan bahwa media komunikasi pembelajaran e4.0 belum bisa menjadi media komunikasi dua arah yang bisa dilakukan antara dosen dan mahasiswa, hal tersebut sejalan dengan apa yang dikatakan oleh (Bullen, 2001; dan Beam, 1997) dalam Chandrawati (2010) mengenai kekurangan dari media komunikasi pembelajaran e-learning yaitu, kurangnya interaksi antara dosen dan mahasiswa atau bahakan antar siswa itu sendiri. Kurangnya interaksi ini bisa memperlambat terbentuknya values dalam proses pembelajaran.

Dimensi hypertext sebesar $77,1 \%$ dengan jumlah responden sebanyak 74 orang menjawab setuju yaitu pada penyataan 13 yang menyatakan bahwa responden merasa dapat mengakses tautan link yang diberikan dosennya pada media e4.0. Dosen dan mahasiswa dapat berkreasi dan manfaatkan kreatifitas bentuk kegiatan belajar mengajar melalui elearning, linklink yang dikirim bisa berisi konten-konten yang mendukung pemahaman peserta didik.

Pada variable $X$ yang lain, dimensi jaringan jawaban yang paling banyak mendapat jawaban setuju yaitu pada pernyataan 19 sebesar $70,8 \%$ dengan jumlah responden sebanyak $68 \%$ menyatakan dapat menemukan kembali file atau dokumen yang pernah di upload di website e4.0 selama mereka terhubung jaringan internet. Selanjutnya pada dimensi virtual pernyataan 25 merupakan pernyataan yang paling banyak mendapatkan jawaban setuju yaitu sebanyak 73 responden dengan persentase $76 \%$ menyatakan dapat mengunduh data-data sebelum ataupun sesudah mata kuliah berlangsung di website e4.0. Hal tersebut mengartikan bahwa peserta didik dapat diberikan kebebasan mengakses data ataupun materi perkuliahan tanpa dibatasi ruang dan waktu, sesuai dengan kebutuhan mereka masinh-masing, misalnya mengulang materi yang belum dipahami Ketika perkuliahan daring dilakukan, hal tersebut sejalan dengan pernyataan Prayogi dkk (2015) yaitu Indikator Waktu dan Tempat Belajar memiliki hubungan nyata dengan indikator kebutuhan pemahaman, yang bermakna sistem elearning yang tidak tergantung pada jam belajar dan tempat belajar membuat siswa lebih fleksibel dalam belajar sehingga meningkatkan tingkat pemahaman dalam setiap persoalan dalam belajar.

Pada dasarnya, e-learning memiliki dua tipe yaitu synchronous dan asynchronous. Jawaban responden mengartikan bahwa mereka dapat mengakses kembali file atau dokumen yang pernah di upload-nya di lain waktu dan tidak bersamaan dengan aktivitas kuliah secara langsung, hal tersebut disebut Asynchronous berarti tidak pada waktu bersamaan. Asynchronous training popular dalam e-learning karena peserta didik dapat mengakses materi pembelajaran dimanapun dan kapanpun, Hartanto (2016).

Dimensi terakhir pada variable $\mathrm{x}$ yaitu simulasi, jawaban pada dimensi ini rata-rata menjawab tidak setuju, dan yang paling yaitu pada pernyataan 27 dengan jumlah persentase $57,3 \%$ dan 55 responden yang menjawab tidak merasa e4.0 dapat melakukan tanya jawab seperti kelas tatap muka pada umumnya. Jawaban dari responden menggambarkan bahwa media komunikasi pembelajaran e-learning 4.0 memiliki kelemahan yaitu Penggunaan elearning sebagai pembelajaran jarak jauh, membuat peserta didik dan pengajar/guru terpisah secara fisik, demikian juga antara peserta didik satu dengan lainnya. Keterpisahan secara fisik ini bisa mengurangi atau bahkan meniadakan interaksi secara langsung antara pengajar dan peserta didik. Kondisi itu bisa mengakibatkan pengajar dan peserta didik kurang dekat sehingga bisa mengganggu keberhasilan proses pembelajaran, Sari (2015).

Berdasarkan hasil kuesioner pada variable $Y$ yaitu Efikasi mahasiswa UPNVJ angkatan 2019, dimensi yang digunakan diantaranya ada tingkatan (level), kekuatan (strength), dan generality. Jawaban terbanyak berada pada kategori tidak mampu dan mampu. Jawaban tidak mampu terbanyak yaitu dimensi generality pada pernyataan 43 , dengan jumlah persentse sebesar $56,3 \%$ dan total responden sebanyak 54 , responden yang menjawab tidak mampu merasa tidak dapat (tidak yakin) menyikapi masalah teknis yang terjadai di e4.0 dengan sikap positif pada saat perkuliahan berjalan. Hal demikian merupakan gambaran dari hasil pengalaman belajar mereka menggunakan media e4.0 Sedangkan kategori jawaban mampu terbanyak yaitu pada pernyataan 42 dengan jumlah persentase sebesar $81,3 \%$ dan total responden sebanyak $78 \%$, menyatakan mampu mengerjakan soal-soal ujian yang diupload melalui e4.0.Menurut Bandura (dalam Suseno, 2012)Efikasi diri akan meningkat jika 
seseorang mendapatkan informasi yang positif tentang dirinya, demikian sebaliknya. Efikasi diri akan menurun jika seseorang mendapatkan informasi negatif mengenai kemampuannya.

Hasil kuesioner pada variable $Y$ yaitu efikasi diri mahasiswa UPNVJ Angkatan 2019 pada penelitian ini, menggambarkan bahwa mahasiswa UPNVJ memiliki keyakinan diri atau mampu melakukan dan menjalankan kegiatan belajar pada e4.0 tetapi tidak memiliki keyakinan diri menghadapi kesulitan teknis pada saat menggunakan e4.0. Hasil perhitungan yang diperoleh melalui uji t yaitu sebesar 4.9538. Penggunaan hasil uji hipotesis adalah untuk menentukan kesimpulan signifikansi dengan membandingkan $t$ hitung dengan $t$ tabel yang nilainya ditentukan pada tingkat signifikansi $10 \%$ dan $\mathrm{df}=\mathrm{n}-2$. Jumlah sampel adalah $96-2=94$. Maka, $\mathrm{t}$ tabel adalah 1.66123. Berdasarkan perhitungan tersebut, hasil perhitungan $t$ hitung $4.9538>t$ tabel 1.66123. Maka, dapat ditarik kesimpulan bahwa $\mathrm{HO}$ ditolak dan Ha diterima yang berarti media komunikasi pembalajaran E4.0 berpengaruh terhadap efikasi diri mahasiswa UPNVJ.

\section{SIMPULAN}

Hasil penelitian menunjukkan bahwa terdapat hubungan yang sedang dan berpengaruh antara e4.0 sebagai media komunikasi pembelajaran terhadap efikasi diri mahasiswa UPNVJ Angkatan 2019 serta data yang didapatkan dari hasil penyebaran kuesioner. Setelah itu, data tersebut diolah dengan menggunakan SPSS versi 26 dan penulis menyimpulkan hasil penelitian sebagai berikut: (1) Berdasarkan hasil perhitungan analisis uji korelasi dari rumus Rank Spearman yaitu terdapat korelasi yang sedang dengan hasil nilai korelasi 0,455 yang terletak diantara $0.41 \mathrm{~s} / \mathrm{d}$ 0.60. Hubungan korelasi yang sedang mengartikan bahwa elearnig 4.0 sebagai media komunikasi pembelajaran memiliki pengaruh terhadap efikasi diri mahasiswa UPNVJ, terutama Angkatan 2019/2020. (2) Berdasarkan hasil perhitungan koefisien determinasi menyatakan bahwa sebesar $20,7 \%$ terdapat pengaruh antara elearning 4.0 sebagai media komunikasi pembelajaran terhadap efikasi diri mahasiswa UPNVJ Angkatan 2019/2020. (3) Berdasarkan hasil perhitungan uji hipotesis yang diperoleh melalui uji t yaitu sebesar 4.9538. Berdasarkan perhitungan tersebut, hasil perhitungan $t_{\text {hitung }} 4.9538>t_{\text {tabel }} 1.66123$. Maka, dapat ditarik kesimpulan bahwa $\mathrm{HO}$ ditolak dan $\mathrm{Ha}$ diterima yang berarti media komunikasi pembalajaran E4.0 berpengaruh terhadap efikasi diri mahasiswa UPNVJ. (4) Hasil penelitian ini menggambarkan bahwa tidak semua mahasiswa mampu menggunakan elearning 4.0 sebagai media komunikasi pembelajaran dikarenakan kurangnya efikasi diri dalam dirinya saat menggunakan media teknologi, ini dibuktikan dengan hasil jawaban kuesioner bahwa mereka merasa tidak mampu untuk menangani kendala teknis atau kesulitan yang dihadapinya pada saat menggunakan elearning 4.0 sebagai media komunikasi pembelajaran. Sehingga ketika mereka menemukan kesulitan dalam menggunakan elearning 4.0 ataupun mendengar hal negative dari penggunaan elearning 4.0 efikasi atau keyakinan diri mereka menurun Selain itu mereka merasa elearning 4.0 belum bisa menggantikan komunikasi dua arah dan komunikasi tatap muka seperti aktivitas mereka di kelas.

\section{DAFTAR PUSTAKA}

Anshori, Shodiq. 2018. Pemanfaatan Teknologi Informasi Dan Komunikasi Sebagai Media Pembelajaran. "Civic-Culture: Jurnal IImu Pendidikan PKn dan Sosial Budaya. ISSN 2579-9924

Aprizal dan Mirfan. 2019. Pelatihan Multimedia Sebagai Media Pembelajaran Di Mis Karama Kab. Bulukumba. STMIK Dipanegara. Makassar. SNP Mas 2019. Depok: PT. Rajagrafindo Persada.

Chandrawati, SR. 2010. Pemanfaatan E-Learning Dalam Pembelajaran. Jurnal Cakrawala Kependidikan. Vol 8 (2).

Effendi, Onong Uchana. 2004. Dinamika Komunikasi. Bandung: Remaja Rosdakarya

Gerlach, Vernon S., and Donald P. Ely. (1971). Teaching and Media: A systematic Approach. Prentice-Hall. Englewood Cliffs. N.J. 
Hartanto, Wiwin. 2016. Penggunaan E-Learning Sebagai Media Pembelajaran. Jurnal Pendidikan Ekonomi: Jurnal IImiah IImu Pendidikan, IImu Ekonomi dan IImu Sosial. Vol $10(1)$.

Kriyantono, R. 2012. "Teknik Praktis Riset Komunikasi Cetakan ke-6”. Jakarta: Kencana Prenada Media Group.

Mulyana, Deddy. 2015. Ilmu Komunikasi Suatu Pengantar. Bandung: Remaja Rosdakarya . 2005. Ilmu Komunikasi Suatu Pengantar. Bandung: PT Remaja Rosdakarya.

Munir. 2010. Prospek Komputer Sebagai Media Pembelajaran Interaktif Dalam Sistem Pendidikan Jarak Jauh di Indonesia. Bandung: Alfabeta

Pengembangan, Pemanfaatan, dan Penilaian. Bandung: CV. Cahaya Prima.

Prasetyo, Bambang dan Lina Miftahul Jannah. (2005). Metode Penelitian Kuantitatif

Rakhmat, Jalaludin. 2008. Psikologi Komunikasi. Bandung. PT. Remaja Rosdakarya.

Rizkiana, Atya. 2017. Pengaruh Self Efficacy Terhadap Hasil Belajar Mahasiswa Berprestasi Mawapres STKIP PGRI Bangkalan.

Rusman. 2011. Pembelajaran Berbasis Teknologi Informasi dan Komunikasi. Bandung. Rajawali Pers

Rustika, IM. 2012. Efikasi Diri: Tinjauan Albert Bandura. Jurnal Psikologi. Vol 20 (1-2).

Sartika Dewi, Haryati TS, Noviestrasi Enie. 2014. Self Eficacy Perawat Dalam Penggunaan Sistem Informasi Keperawatan Di RSIA Bunda Jakarta: Studi Fenomenologi. Jurnal Keperawatan Indonesia, Vol 17, No.2. pISSN 1440-4490, eISSN 2354-9203.

Sihaloho, Lasmita. 2018. Pengaruh Efikasi Diri (Self Efficacy) Terhadap Hasil Belajar Ekonomi Siswa Kelas XI IPS SMA Negeri Se-Kota Bandung. Jurnal Inovasi Pembelajaran (4) 1. DOI: $10.22219 /$ inop.v4i1.5671

Sujianto, A.E. (2009). Aplikasi Statistik Dengan SPSS. Jakarta : Prestasi Pustaka.

Susilana, Rudi, dan Cepi Riyana. 2009. Media Pembelajaran: Hakikat.

Wibisono, Gunawan. 2017. Media Baru dan Nasionalisme Anak Muda: Pengaruh Penggunaan Media Sosial 'Good News from Indonesia' Terhadap Perilaku Nasionalisme. Jurnal Studi Pemuda. (6)2

Wonodihardjo Felicia. 2014. Komunikasi Kelompok yang Mempengaruhi Konsep Diri Dalam Komunitas Cosplay "COSURA” Surabaya. Jurnal E-Komunikasi, Vol 2 No.3.

\section{Sumber Lain}

Kemendikbud (2020). Pusat Pendidikan dan Pelatihan Pegawai,diakses pada 31 Juli 2020, pada:https://pusdiklat.kemdikbud.go.id/surat-edaran-mendikbud-no-4-tahun-2020tentang-pelaksanaan-kebijakan-pendidikan-dalam-masa-darurat-penyebaran-coronavirus-disease-covid-1-9/

Portal Berita UGM. (2020). Membedah Tantangan Pembelajaran Daring di Tengah Pnademi Covid-19, diakses pada tanggal 31 Juli 2020, pada: https://ugm.ac.id/id/berita/19552membedah-tantangan-pembelajaran-daring-di-tengah-pandemi-covid-19. 